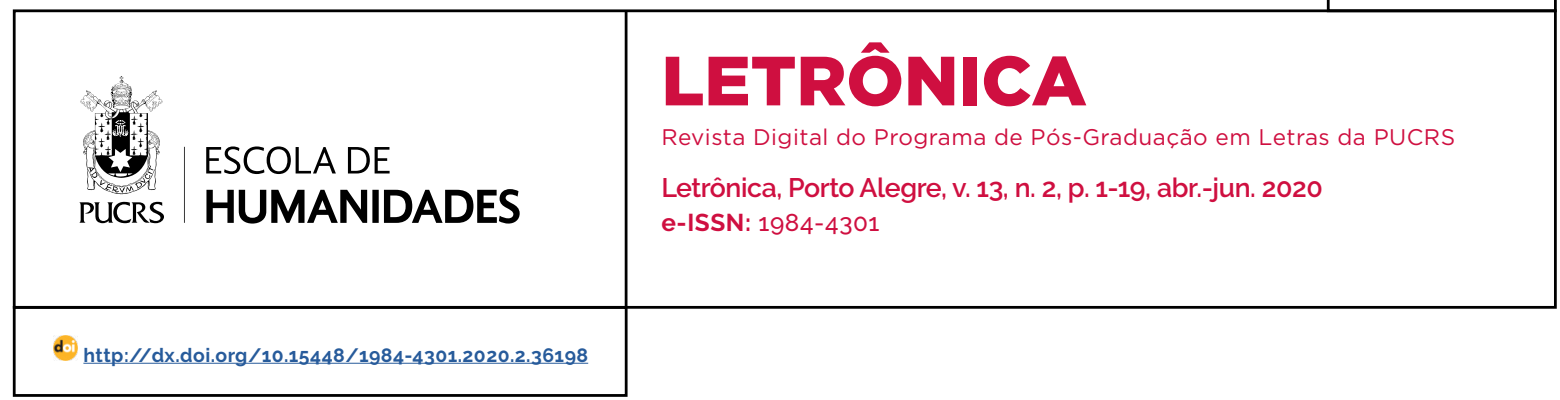

\title{
Minions nas telas e bolsominions na vida: uma análise bakhtiniana
}

\author{
Minions on the screens and bolsominions in life: a bakhtinian analysis
}

\section{Luciane de Paula ${ }^{1}$ \\ orcid.org/0000-0003-1727-0376 \\ lucianedepaula1@gmail.com}

\section{Natasha Ribeiro de \\ Oliveira $^{1}$ \\ orcid.org/0000-0001-8760-8104 \\ nariiibeiro@gmail.com}

Recebido em: 29 out. 2019

Aprovado em: 24 mar. 2020

Publicado em: 13 ago. 2020
Resumo: O estudo, embasado na filosofia bakhtiniana, tomada a partir da noção de linguagem como entendida por Paula (2017a, 2017b, 2017c, 2019a, 2019b) - de maneira tridimensional - verbivocovisual, tem como objetivo refletir acerca do sujeito em rede, denominado bolsominion, em páginas do Facebook. Para tanto, partimos de um corpus constituido por uma franquia de filmes intitulada Meu Malvado Favorito (2010, 2013, 2015 e 2017), que apresenta a ideia do que é ser minions, enquanto sujeito, para, então, podermos expandir essa concepção para o contexto político brasileiro a partir do termo "bolsominion", num movimento dialético-dialógico que compreende o embate de forças entre valores opostos, sem solução. Entende-se o termo, de acordo com o uso, como um signo ideológico e percebe-se como um determinado conteúdo temático, que provém da arte é elaborado de maneira estética e, posteriormente, volta-se para o solo social com uma nova significação, e adquire, como no caso deste estudo, uma crítica a um grupo específico, pois se aproveita de características presentes na franquia de filmes para estabelecer uma relação entre a vida e a arte - a constituição dos sujeitos minions paralela à constituição dos sujeitos bolsominions. O resultado demonstra que um discurso intolerante está associado a esse grupo ("bolsominion"), como uma de suas caracteristicas de existência nas redes sociais e fora delas.

Palavras-chave: Minions. Signo ideológico. Diálogo.

Abstract: The study, based on Bakhtinian philosophy, taken from the notion of language as understood by Paula ((2017a, 2017b, 2017c, 2019a, 2019b) - in a three-dimensional way - verbivocovisual, aims to reflect on the networked subject, called bolsominion, on Facebook pages. To this end, we start from a corpus made up of a movie franchise entitled Despicable Me (2010, 2013, 2015 and 2017), which presents the idea of being minions as a subject, so that we can expand this conception to the Brazilian political context from the term "bolsominion", in a dialectical-dialogical movement that comprises the clash of forces between opposing values, with no solution. Thus, the term, according to its use, is understood as an ideological sign and it is perceived as a certain thematic content, which comes from art, is elaborated aesthetically and, later, turns to the social soil with a new meaning, and acquires, as in the case of this study, a criticism of a specific group, because they take advantage of features present in the movie franchise to establish a relationship between life and art - the constitution of minions subjects parallel to the constitution of the bolsominions subjects. The result demonstrates that an intolerant discourse is associated with this group ("bolsominion") as one of its characteristics of existence on social networks and beyond them.

Keywords: Minions. Ideological sign. Dialogue.

\section{Introdução: diferentes significações em diferentes telas}

De acordo com a filosofia bakhtiniana, arte e vida são indissolúveis e o enunciado artístico, reflexo e refração sociais. Não é possivel pensar o estético apartado de seu contexto valorativo sociocultural. A partir dessa noção, temos em vista uma "febre amarela minions" (OLIVEIRA, 2020) que invadiu e tem invadido a sociedade nos mais diferentes niveis: personagens que saíram das telas de cinema e hoje são encontrados 
em prateleiras de lojas e supermercados, com várias finalidades; páginas de redes sociais (como o Facebook) com as personagens, com diversos fins; e o desdobramento da designação "minions" para caracterizar um grupo específico los eleitores do Presidente Jair Messias Bolsonaro, chamados de "bolsominions"), na esfera política.

A indagação que nos move é: como o que está presente nas telas de cinema é reelaborado para outro plano? A arte, vinda do cotidiano e das suas relações intersubjetivas, volta a ela, de maneira refletida e refratada. Uma variedade do social, o estético, com seu acabamento específico, está apoiado no concreto. O que consumimos como enunciado filmico, como post de internet e como designação política é uma das formas de compreensão do social e dos sujeitos presentes nas mais diversas relações.

Compreender como os minions saem das telas de cinema e ganham novas significações, em outras telas, como reflexo e refração da vida, principalmente ao considerarmos o cenário político brasileiro, ao pensarmos a produção, a circulação e a recepção do fenômeno "febre amarela 'minions'" (OLIVEIRA, 2020) é o nosso objetivo central. Para tanto, trazemos os filmes da franquia Meu Malvado Favorito (2010, 2013, 2015, 2017) como uma forma de compreensão inicial dos sujeitos minions e seu diálogo com os bolsominions, designação ressignificada a partir das animações.

Nos enunciados fílmicos da franquia, a ideia de ser minion está calcada em uma relação de alteridade com Gru, o sujeito-outro dos minions, tomados como sujeitos-eus. Para eles, que se configuram como súditos fiéis, ter um patrão mau (o pior) a quem servir compõe o sentido de sua existência. Se eles não têm um "malvado favorito" que thes escraviza, adoecem mentalmente pela ausência de servidão, como ocorre nas animações (em especial, em Minions, 2015). Gru é, para eles, mais do que um patrão que ordena e explora: Gru é o que permite que eles sejam (e continuem a ser) minions.
A partir dessa relação é que surge o termo "bolsominion" para caracterizar um grupo eleitoral político no cenário brasileiro das eleições presidenciais de 2018. O termo, entendido como um signo ideológico, proliferou, principalmente, nas redes sociais, em específico, no Facebook ${ }^{2}$, uma plataforma que permite aos sujeitos atuarem como curtidores, comentadores e compartilhadores de ideias. Nesse ambiente, o termo surgiu como uma crítica satírica para designar o grupo de eleitores que apoiaram e apoiam o político como servos cegos, amparados por um momento político atípico vivenciado, a "era da pós-verdade", caracterizada pelo tsunami das fake news. O discurso de ódio é o mote desse grupo de eleitores/seguidores designados como "bolsominions".

Uma ressignificação foi criada, a partir da obra filmica, no solo social cotidiano das redes para o que é ser (bolso)minion: apoio incondicional a um candidato político. Como minions, os eleitores bolsonaristas atuaram e atuam como servos, consideram seu candidato/presidente um "mito" e se apropriaram do termo "bolsominions" com outra valoração para confirmarem sua condição de súditos ímpares, inabaláveis, apoiadores independente das ações e declarações consideradas racistas, machistas, homofóbicas, retrógradas em todos os sentidos, com relação à educação, à ciência, ao meio ambiente, à agricultura, à tecnologia, à pesquisa etc - do "amo" que escolheram servir, por identificação (a ponto de postarem, no Facebook, no Youtube, no WhatsApp, no Instagram, no Twitter etc, que eram "o caixa 2 do Bolsonaro", como justificativa ao crime eleitoral cometido, visto por eles como natural ou mentiroso). A intolerância com qualquer diferente é uma das marcas desse grupo (candidato/presidente e eleitores).

O armamento, a violência (simbólica - como a verbal e a gestual - e física), a corrupção (aparentemente combatida, mas instituida), a familia (heteronormativa), a religião, a tradição e o conservadorismo são alguns dos traços que

O Facebook foi a plataforma escolhida por ser nela que o termo surgiu e também por oferecer maior regularidade e variedade de páginas e posts, atualizados de maneira dinâmica. Os critérios para a seleção do objeto aqui analisado se referem à recorrência temática e figurativa (definição de "bolsominions"), cronologia (periodo pesquisado), elementos quantitativos (páginas com maior número de seguidores, post de maior visualização) e à relação entre esferas e produções (artística, midiática e política). 
caracterizam esses sujeitos. A crítica realizada pelo termo "bolsominions", como veremos, pauta-se nas ações do próprio grupo, com suas contradições e preconceitos ancorados no discurso do candidato/presidente ("Malvado Favorito") ao qual apoiam.

A significação não é estática. Afinal, a língua é viva. Assim sendo, o grupo denominado "bolsominions", ao se aperceber da denominação a ele direcionada, muda o sentido crítico do termo e se apropria dele, ao imputar-lhe uma significação positiva, de fidelidade, amizade e lealdade. Ao esvaziar o termo de sua significação inicial, gera outros sentidos para o tema ser minion.

A viralização do termo, com a polissemia que adquiriu, foi tamanha que ele passou a habitar o cotidiano das conversas dos mais variados grupos, em diversas situações, seja de maneira critica e negativa, seja como aceitação positiva e é isso que justifica o estudo feito por nós: compreender como um termo ganha essa proporção e transita entre esferas, gêneros, sujeitos e situações heterogêneas.

A movimentação em jogo foi e é tamanha que o termo até perdeu o prefixo ("bolso") que atrelava o termo e o sujeito original das animações (minion) ao então candidato a quem a designação se referia (Bolsonaro). A razão foi a incorporação, tanto pelo grupo que critica quanto pelo que assimila as valorações ambivalentes contidas no signo. Hoje, o termo minion, a depender do contexto situacional, já basta para se referir aos eleitores de Bolsonaro. Esse processo ocorreu, como veremos, porque o signo (sempre ideológico, conforme os estudos bakhtinianos - cunhado por Volóchinov) passou a constituir o perfil de um grupo, que se assume minion. O que surge como uma designação crítica satírica se transforma em marca identitária. Identidade constituída pela alteridade. Um outro grupo começou a se referir aos eleitores de Bolsonaro dessa maneira e estes incorporaram o termo, com outra significação axiológica.

O confronto entre o que é negativo e criticado por um grupo (a alienação servil da mão de obra escrava representada pelos trabalhadores/ operários amarelos por escolha própria nas animações), é entendido como motivo de orgulho por outro, que se vê fiel aos valores expressos pelo candidato/presidente: nacionalismo, conservadorismo, saudosismo, militarismo, armamento etc. Essas ideias que, para um grupo, são retrógradas, constituem a caracterização do perfil tanto do Bolsonaro quanto de seus eleitores, como "defesa" à pátria, à moral e aos "bons costumes". Ser minion, para esse grupo, significa ser "cidadão de bem", que se "sacrifica" e se submete a tudo, em prol da "melhoria" de uma nação, mesmo que hipocritamente.

Para melhor compreender esse processo, a nossa proposta neste artigo se volta à noção de signo ideológico, dialogia, tema e significação na língua, como uma forma de compreensão de sujeitos situados espacial e temporalmente como responsivos e responsáveis por seus atos. O método dialético-dialógico, realizado por cotejo, permite-nos pensar questões acerca da linguagem, por não conceber os enunciados como acabados, mas como elos na cadeia da comunicação discursiva, em que um enunciado responde a outro(s), retrospectiva e prospectivamente, sem sintese conclusiva, mas em movimento espiralado com maior e menor tensão. A relevância de estudos de movimentos como esse, realizados, sobretudo, a partir de e nas redes sociais (nesse caso, no Facebook), volta-se à compreensão de interações sociais e seus trânsitos em diversas esferas. O ambiente digital cria sentidos como reflexo e refração sociais, ao mesmo tempo em que contribui para a construção de valores nessa sociedade. A contemporaneidade se comunica por meio de telas e, por meio delas, reflete e refrata o mundo, via signos ideológicos, concebidos como tridimensionais (verbivocovisuais), de acordo com Paula (2017a, 2017b, 2017c, 2019a, 2019b). Signos ideológicos que re-velam sujeitos e culturas. E essa é a importância da reflexão aqui empreendida.

\section{A filosofia da linguagem bakhtiniana: linguagem, ideologia e sujeito}

Alinguagem, parao Circulo de Bakhtin, é concebida de diferentes formas: como atividade voltada à dimensão da vida, como ato único, carregada de expressividade e atitude valorativa dos sujeitos em 
relação ao seu objeto discursivo. Concretizada em enunciado e este ligado às situações sociais de sua realização. Concebida como enunciado, como singular, plurivalente e irrepetivel, tem como base as relações dialógicas (entre enunciados e sujeitos) com base material diversa.

Volochinov diz que a linguagem é a responsável pela formação dos "....] sistemas ideológicos, a ciência, a arte, a moral, o direito, e ao mesmo tempo a linguagem cria e forma a consciência de cada homem" (2013, p. 155). Ela nos permite construir visões de mundo acerca do que nos cerca, de forma que nossos enunciados passam a ser concebidos como manifestações situadas, social, cultural e historicamente, uma vez que não há como pensar na linguagem apartada de um contexto específico de uso, em um modo abstrato de produção e compreensão. A linguagem não é constituída por um sistema abstrato, mas pelo fenômeno da interação verbal, realizado por meio de enunciados entre sujeitos (de linguagem), igualmente situados.

Faraco (2009, p. 23-24) aponta que, em Para uma filosofia do ato responsável (2010), Bakhtin afirma que "[...] a linguagem aparece já apresentada [...] como atividade (e não como sistema) e o enunciado como um ato singular, irrepetivel, concretamente situado e emergindo de uma atitude ativamente responsiva". Há valorações relacionadas a determinadas situações espaçotemporais e a determinados sujeitos. A interação é dinâmica e revela posições axiológicas em jogo, em constante embate social.

Volóchinov trata o signo como materialização da comunicação (2017, p. 98), em que a palavra (no sentido amplo, alargado, de linguagem e discurso) assume o caráter de fenômeno ideológico. $\mathrm{O}$ estudo dos signos ideológicos é uma forma de compreender os sujeitos que os compõem, pois, como a concebe o Círculo bakhtiniano, a palavra é "o médium mais apurado e sensivel da comunicação social" (VOLÓCHINOV, 2017, p. 99). A potencialidade da linguagem, aberta e tridimensional ("linguagem das linguagens", como denomina Volóchinov) abarca as possiblidades de materialização enunciativa que podem enfatizar uma ou mais dimensões, a depender da configuração.

A palavra abstrata, tomada como signo sistêmico/linguístico, de acordo com Volóchinov (2017, p. 99) é neutra em relação a qualquer função ideológica específica porque comporta diversas e diferentes possiblidades de utilização e atualização, ou seja, é prenhe de valorações. A palavra/signo linguístico é um traço porque se comporta como um lexema, uma cor, um som, de modo que não se limita a um campo específico. Isso nos remete à ideia de Paula (2017a, 2017b, 2017c, 2019a, 2019b) sobre a verbivocovisualidade, uma noção de linguagem como tridimensional, proveniente dos estudos da poesia concreta, que a vê como expressão de máxima potência verbivocovisual, com a ideia de sair do papel e ganhar o mundo por meio das dimensões verbal, vocal e visual, numa concretude enunciativa especifica. Paula pensa que os estudiosos do Círculo (em especial, Volóchinov, mas também Bakhtin, Medviédev e Sollertinski) têm a noção dessa tridimensionalidade e a consideram ao pensarem sobre uma espécie de próto-linguagem e sua materialização, o que desenvolvem ao tratarem da linguagem como ato, concretizada em enunciado, por signos ideológicos que não se limitam ao signo verbal, mas também aos traços, cores, ângulos, sons, entoações etc, na constituição arquitetônica de dado discurso, como será o caso dos fotogramas colhidos dos filmes de animação e dos posts retirados do Facebook aqui analisados.

Ambas as noções, de potencialidade e a de materialidade da linguagem, seja em qual tipo de enunciado for, são uma forma de observar o mundo que nos cerca mediante os aspectos sígnicos dos enunciados (uma pintura, uma canção, um filme, um bilhete, um romance, dentre tantas outras possibilidades), pois neles teremos as dimensões de linguagem materializadas como elementos de constituição integral enunciativa. Desse ponto de vista, podemos pensar tanto na franquia de enunciados filmicos quanto nas respostas que surgem a partir deles nas redes sociais, no cenário político brasileiro, como enunciados verbivocovisuais, em que o verbal, o vocal/sonoro e o visual compõem a unidade sincrética que expressa significações que nos revelam os posicionamentos valorativos dos 
sujeitos-autores, como consideraremos nas análises empreendidas, calcadas nas noções bakhtinianas mencionadas.

Pensamos nessas três dimensões - verbal, vocal/musical e visual - como unicidade arquitetônica, o todo enunciativo, não como partes isoladas. Ao falarmos de um enunciado fílmico, por exemplo, observamos como essas dimensões constroem o sentido, mediante as posições de câmera, o figurino, a trilha sonora, os tópicos frasais, as colorações, as entoações e ritmos de fala, a disposição dos sujeitos na cena, o cenário, a iluminação, a maquiagem, a coloração etc. Mesmo quando não há a materialização explícita de uma das dimensões, ela se encontra "virtualmente" presente, como potencialidade mental. Daí a afirmação de Paula que todo enunciado é verbivocovisual.

Embora o Círculo bakhtiniano tenha se dedicado, principalmente, ao estudo do verbal (com o romance, mais especificamente), encontramos, nos próprios escritos dos autores, a ideia de uma linguagem que comporta essas dimensões, sendo que Paula (2017a, 2017b, 2017c, 2019a, 2019b) vê essa concepção como uma forma de colocar em jogo as formas renovadas de experiência de linguagem, especialmente as materializações sincréticas contemporâneas. Volóchinov (2017), por exemplo, diz que o caráter sígnico é comum a todos os fenômenos ideológicos, de modo que

[...] qualquer signo ideológico é não apenas um reflexo, uma sombra da realidade, mas também uma parte material dessa mesma realidade. Qualquer fenômeno ideológico sígnico é dado em algum material: no som, na massa física, na cor, no movimento do corpo e assim por diante (2017, p. 94, grifo nosso).

Por isso, podemos dizer que as diferentes dimensões da linguagem estão presentes de maneira explicita ou potencial em todos os enunciados e podem (ou não) ser expressas em suas diferentes materialidades. Analisamos os enunciados, de qual gênero discursivo for, ao considerarmos a sua potencialidade expressiva. Essas questões estão marcadas no enunciado mediante os signos ideológicos que revelam, segundo Volóchinov
(2017), os diferentes sujeitos e o seu modo de relacionamento e posicionamento no mundo.

O autor afirma que "[...] Tudo o que é ideológico possui uma significação: ele representa e substitui algo encontrado fora dele, ou seja, ele é signo" (p. 91, grifo do autor). Pensar o signo ideológico "bolsominion" desse ponto de vista é a nossa proposta, uma vez que passou a ser uma questão identitária, não só de designação linguística (nomeação realizada por uma adjetivação substantivada), mas também de afirmação de um grupo e de uma voz social de posicionamento (político) axiológico, calcado em dois pontos de vista distintos: de um lado, a crítica pela alienação, fundamentada no comportamento servil dos minions (operários explorados em todos os sentidos, que, mesmo sem uma língua articulada e sem argumentação que explicite a coerência de seu pensamento e de seus atos, como robôs que se comportam massivamente, seguem, como uma legião - um exército, por livre e espontânea vontade, um lider/"mito". Não um qualquer, mas o mais "Malvado Favorito", escolhido/eleito por eles, marcado, no título da animação pelo possessivo "Meu" - o que revela o ponto de vista narrativo da trama e identifica os minions amarelos do filme com o telespectador particularizado, ainda que massivo - o público, devido ao uso do pronome na primeira pessoa do singular) e, de outro, a apropriação do termo ressignificado como signo de nacionalismo e fidelidade, fundamentado em valores tradicionais e conservadores que envolvem, no mínimo, a esfera religiosa (o "Messias" salvador) e a familiar (e, como familia, em contato com o discurso da Igreja, esse grupo admite apenas a estruturação heteronormativa canônica), sempre em prol do econômico que, como diria Marx, é a base do sistema capitalista.

Os minions, nesse sentido, autodesignam-se súditos não apenas de um sujeito que elegem como seu "Meu Malvado Favorito", mas o escolhem pelos valores que ele representa e que são, de fato, o que procuram seguir, de forma hipnótica: a mentalidade de um Brasil com "síndrome de cachorro vira-lata", ainda colônia de exploração (outrora, submetido a Portugal e, agora, por livre escolha, aos Estados Unidos) que não vê que 
possui sua autonomia e prefere, ao invés de viver seus valores com atos independentes, obedecer alguém, com quem se identificam como igual (o sujeito eleito é tão subserviente e minion quanto seus eleitores, num outro nível, pois o "Malvado Favorito" escolhido por ele para seguir é Trump, nesse momento, lider máximo/presidente norteamericano; e Ustra, o maior torturador do Brasil).

Nesse sentido, o líder eleito e seguido desempenha dupla função, a depender do lugar do qual se vê: no Brasil, para um grupo de sujeitos (os eleitores-seguidores), ele é o "Mito", o "Messias" "salvador de pátria" autêntico em suas falas; para outro (os não eleitores do Presidente), seus atos de "Malvado Favorito" são considerados contraditórios e calcados em valores machistas, racistas e homofóbicos que instigam, de maneira autoritária, ódio separatista, purista e misógino de destruição de tudo e todos, em nome de "Deus", "da moral e dos bons costumes", da "familia" e da "cristandade", apoiado na violência simbólica e física do armamento com a linguagem e os atos desrespeitosos e retrógrados, baseados numa honestidade e numa justiça inexistentes, pois sustentada por privilégios para si e desmonte tirânico de quaisquer direitos aos demais humanos, trabalhistas, de gêneros, entre outros.

Procuramos compreender quais as significações que atravessam o signo ideológico "(bolso)minion" sem perder de vista os enunciados filmicos de onde surgem, a fim de estabelecermos o diálogo que revela o reflexo e a refração desse signo ideológico, que ultrapassa fronteiras e esferas. Volóchinov diz que

O signo não é somente uma parte da realidade, mas também reflete e refrata uma outra realidade, sendo por isso mesmo capaz de distorcê-la, ser-lhe fiel, percebê-la de um ponto de vista específico e assim por diante. As categorias de avaliação ideológica (falso, verdadeiro, correto, justo, bom etc.) podem ser aplicadas a qualquer signo. O campo ideológico coincide com o campo dos signos.
[...] Onde há signo há também ideologia. Tudo o que é ideológico possui significação signica (VOLÓCHINOV, 2017, p. 93, grifo do autor).

Por meio do método dialético-dialógico ${ }^{4}$ (PAULA; FIGUEIREDO; PAULA, 2011), analisamos os enunciados, em cotejo com outros, a fim de compreender a relação existente entre eles, não como uma sintese dialética nem uma superação entre si, mas pela constante interação de opostos que convivem e se alteram e alternam (como euoutro sujeito e enunciado). Bakhtin, em Estética da criação verbal (2011), no ensaio "Metodologia das ciências humanas", sintetiza a ideia de diálogo:

Não existe a primeira nem a última palavra, e não há limites para o contexto dialógico (este se estende ao passado sem limites e ao futuro sem limites). Nem os sentidos do passado, isto é, nascidos no diálogo dos séculos passados, podem jamais ser estáveis (concluidos, acabados de uma vez por todas): eles sempre irão mudar (renovando-se) no processo de desenvolvimento subsequente, futuro do diálogo. Em qualquer momento do desenvolvimento do diálogo existem massas imensas e ilimitadas de sentidos esquecidos, mas em determinados momentos do sucessivo desenvolvimento do diálogo, em seu curso, tais sentidos serão relembrados e reviverão em forma renovada (em novo contexto) (BAKHTIN, 2011, p. 410).

Compreendemos o diálogo sem conseguir dissociá-lo de outras ideias presentes no pensamento do Círculo, uma vez que a expressão de um sujeito, em um determinado tempo-espaço, situado e contextualizado, produz um enunciado que responde, ativamente, a outros enunciados e, consequentemente, a outros sujeitos, valorações, vozes etc. As publicações que analisamos trazem o conteúdo temático sobre os bolsominions, com forma e estilo próprios, de maneira única, produzidas em um momento da história específico, por sujeitos singulares, ao mesmo tempo que elos na cadeia discursiva por manterem diálogos com enunciados passados e futuros.

\footnotetext{
3 Não adentraremos nessa relação, apenas mencionada aqui, pois ela será pauta central de outro artigo. Assim, não fugimos da proposta deste texto.

4 Assumimos a designação adotada por Paula, Figueiredo e Paula por concebermos o jogo dialógico proposto pelo Círculo bakhtiniano em movimento dialético, como o método sociológico (assim chamado por Volóchinov, em seu ensaio "Discurso na vida e discurso na arte") materialista histórico (logo, marxista) - não por acaso, Volóchinov escreveu o livro Marxismo e Filosofia da Linguagem. Diferente de pensar a dialogia como método que encara apenas o embate de vozes sociais num determinado nivel, a dialética-dialógica considera esse embate em niveis hierárquicos em movimento, sem compreender a sintese como solução generalizante, mas como um novo passo que engata o discurso no movimento dialógico, num outro nivel. Compreender dessa maneira o método bakhtiniano significa entender a complexidade da linguagem como reflexo e refração sócio cultural e histórico. Não como produto estagnado, mas em constante processo potencial, como ocorre com o signo ideológico "minion", como temos visto aqui, que assume significações distintas, a depender do grupo e suas valorações.
} 
A questão do enunciado dialógico passa a ser uma forma de leitura do termo "bolsominions", pois, ao visualizarmos as construções originais (no sentido de primeiras) acerca do termo, elas foram as que possibilitaram a ressignificação e consequente identificação e afirmação do signo, uma vez que nasceram como enunciados responsivos (respostas) e responsáveis (posicionamentos) aos enunciados de crítica satírica. Volóchinov ressalta que "a palavra é o fenômeno ideológico par excellence". (2017, p. 98, grifo do autor), sendo ela o mais apurado e sensivel mediador da comunicação. Desse fato decorre, também, ser a palavra o mais representativo dos signos, além de poder assumir qualquer função ideológica.

A realidade do signo está localizada entre os sujeitos e é produzida por meio do organismo individual (VOLÓCHINOV, 2017, p. 100). O autor explica que "todas as manifestações da criação ideológica, isto é, todos os outros signos não verbais são envolvidos pelo universo verbal, emergem nele e não podem ser nem isolados, nem separados dele por completo" (2017, p. 100101, grifo nosso). Embora a palavra seja retratada como o signo ideológico por excelência, não se descarta o estudo feito com outras materialidades sígnicas, que contêm diferentes dimensões e materialidades da linguagem, porque nelas encontramos as valorações presentes e resultantes das interações sociais em outras formas de constituição sígnica.

\section{Minions na arte, bolsominions na vida}

Um enunciado está ligado ao seu tempoespaço de produção (cronotopo) e às valorações que circulam no interior de um determinado grupo social, do qual ele faz parte. As compreensões acerca do enunciado também são feitas a partir do mundo que circunda os sujeitos consumidores. Nesse sentido é que pensamos a criação do termo "bolsominions" (associação do político Bolsonaro com os minions, feita a partir dos enunciados filmicos da franquia Meu Malvado Favorito).

Bakhtin (2014, p. 211) diz que o processo de assimilação do tempo, do espaço e do sujeito é complexa e intermitente. O sujeito se revela no tempo-espaço, no cronotopo. O cronotopo desempenha papel fundamental para nos mostrar quais são os enunciados, elaborados dentro de um gênero discursivo, que revelam os conteúdos sobre os quais uma sociedade ou um grupo fala a respeito. Isso justifica o tratamento de publicações de Facebook (com os critérios de coleta de dados já mencionados na nota de rodapé 1) como enunciados-respostas ao momento político vivenciado. Os fotogramas aqui analisados revelam a hierarquia entre sujeitos para demonstrar a relação dos minions e dos bolsominons com seus respectivos Malvados Favoritos, assim como os posts selecionados tiveram como base o critério temático de definição de bolsominions (em sua relação com os filmes de animação e com o político que seguem) e "bolsolindas" (considerando a relação de gênero e também o contexto do movimento "Ele não", encabeçado por mulheres consideradas, por determinado grupo social, como "feministas"); além do critério temporal para os posts (ano de 2018, periodo próximo à eleição presidencial daquele ano, quando o termo "bolsominion" viralizou e se consolidou na esfera politica) e ainda o quantitativo (a expressividade da viralização desses posts, muito visualizados e compartilhados, logo, com muita circulação, comentários etc). Com esses critérios, ilustramos, de maneira qualitativa, a relação arte e vida (mídia e política) e demonstramos o movimento dialéticodialógico do signo ideológico, considerando os estudos bakhtinianos acerca da linguagem, em sua constituição verbivocovisual.

Ao que tange às mídias sociais, em consonância com Lévy (2000) e Jenkins (2009), pensamos no ciberespaço como um local virtual-real que possibilita o surgimento de novos tipos de interação, bem como de conhecimento, fazendo-o circular de forma mais fluida e dinâmica. Interessam-nos, para a análise aqui apresentada, as interações entre os sujeitos, mediadas por computadores, mais especificamente, nas redes sociais, em que há a possibilidade de contato e de troca, o que possibilita novas formas de comunicação 
e expressão, fruto da cultura da convergência que tem como mote a cultura participativa, em que os sujeitos não se caracterizam como meros receptores, acriticos e passivos. Ao contrário, são ativamente responsáveis pelo surgimento de novos e diferentes enunciados que coexistem, em embate de forças, com enunciados provenientes de uma grande mídia difusora de conteúdo cultural.

O nosso percurso metodológico se constituiu da seguinte maneira: olhamos, inicialmente, para a caracterização dos minions nos enunciados filmicos, em relação ao Gru (nome do "Malvado Favorito" que seguem). Embora tenham o tom do riso na animação, os minions sustentam uma relação sádica entre si - mas não em relação ao seu chefe, que seguem sem questionamento. Eles riem constantemente, batem ou trapaceiam uns aos outros, o que instaura um embate dialético entre contrários e contraditórios que revela total falta de consciência de classe, pois o sadismo se instaura no próprio grupo social (operário - o que fica caracterizado pelo figurino dos minions), contra os iguais e não contra Gru, o patrão explorador. Pela relação entre minions e Gru, uma imagem de servidão e fidelidade a qualquer custo é criada quase que de maneira despercebida, dada a aparente afetividade e falsa identificação entre eles. Os minions não refletem acerca da plausibilidade das situações a que são submetidos - roubos de monumentos históricos, trapaças e maldades explícitas, serem usados como objetos sem qualquer valor, entre outros. Nada os constrange. Ao contrário, eles estimulam, apoiam e querem fazer parte das experimentações e peripécias do Gru. Isso é o que os constitui como sujeitos (alienados de sua condição de mão de obra explorada, reificados como propriedades privadas do outro-Gru, o dono dos meios de produção).

Os minions agem em coerência com os objetivos de seu líder, no caso, Gru, voltado à realização de feitos vilânicos, e não se voltam para suas individualidades e vontades (embora a vontade - meta de vida - dos minions seja expressa como sendo a servidão, o que coincide com a de Gru, de ser proprietário, ter servos), como é possivel observar em Minions, quando a voz do narrador, que conta a história dos sujeitos amarelos em tom e estrutura semelhante ao de contos de fada, diz: "Eles são diferentes, mas todos têm o mesmo objetivo: servir ao mestre mais perverso que puderem achar. Agradar o mestre era a razão de existência dessa tribo" (COFFIN; BALDA, 20155). Não importa qual seja o mestre, os minions estão aglomerados em torno desse vilão em busca de servidão desde sua origem e ao longo de toda a história:

Figura 1 - Minions e chefes ao longo do tempo
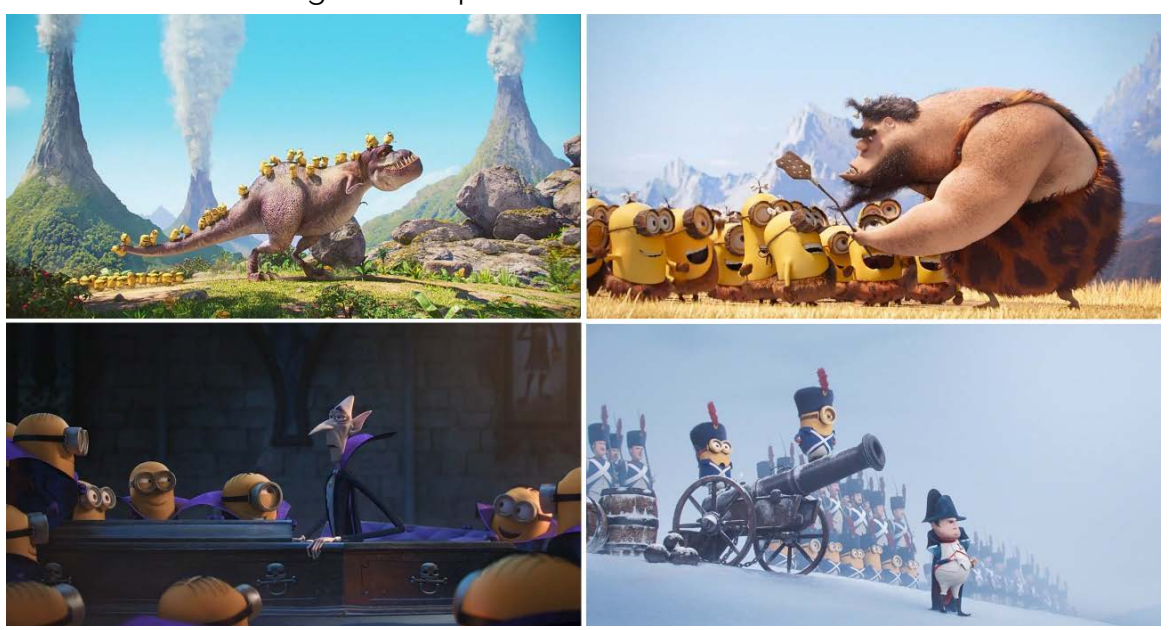

Fonte: Minions (2015). ${ }^{6}$

\footnotetext{
Narrativa explicitada em 00:02:03-00:02:24.

Fotogramas disponiveis em Minions (2015), 00:02:19, 00:03:58, 00:04:29 e 00:04:58, respectivamente.
} 
Os minions passaram muito tempo e passaram por diversos chefes (dinossauro, homem préhistórico, Drácula, Napoleão, entre outros - como visto nos fotogramas que compõem a Figura 1) antes do Gru e, do mesmo modo que serviam aos demais, eles também se colocam ao dispor de Gru. O modo como Gru, considerado o malvado favorito dos minions, trata seus servos, descarta as singularidades de cada minion, transformandoos em uma massa homogênea amarela, sem identidade. Assim, os minions (grupo social) são sujeitos destinados à servidão, sendo que para tal constituição é necessário que exista um vilão, o sujeito "outro" dos minions.

Essa condição de servidão é marcadamente constitutiva, tanto que a própria caracterização dos minions sugere a ideia de trabalho fabril, pois, como vemos pela constituição verbivocovisual de seus seres, as vestimentas demonstram a sua condição laboral, marcada pelo macacão de operário (exceto em Minions (2015), antes de conhecerem e passarem a servir o Gru), não possuem uma lingua articulada compreensivel e se expressam vocalmente pela entoação de entusiasmo com a condição de servidão, rindo uns dos outros. Para eles, sua vestimenta é uma roupa comum, não uma roupa de trabalho, pois são operários em prontidão para o trabalho full time, sem outro sentido de vida nem outras esferas nem condições de vida própria. Mesmo quando se divertem, aparecem em bloco, como um grupo homogêneo, numa espécie de "happy hour", mas sempre a postos, à disposição de Gru, como bons trabalhadores-servos devem se portar - vestindo não apenas a camisa, mas a voz social da empresa e, no caso, do patrão, com outros interesses, diferentes dos seus.

O uso do macacão jeans, em todas as situações, coloca os minions como não conhecedores dos limites do seu local de trabalho (que deveria se fixar no laboratório e num período especifico do dia) e de outros locais, o que revela desconhecimento de si e de sua força de trabalho, bem como falta de consciência de classe, o que constitui o processo de alienação a que se submetem por "vontade própria" (mascaramento da realidade, falseada pelo fetiche da mercadoria como razão de existência, segundo Marx ao analisar as relações de trabalho como estabelecidas no sistema capitalista e ao refletir sobre o processo de alienação - de si, do outro e ente-espécie, que leva à "humanização da coisa" e "reificação do homem"). O macacão traz no bolso central um símbolo em formato de G, em referência a Gru e o visual de trabalhador é completo pelas luvas, pelos óculos e pelos sapatos/botas:

Figura 2 - Vestimenta de operário dos minions

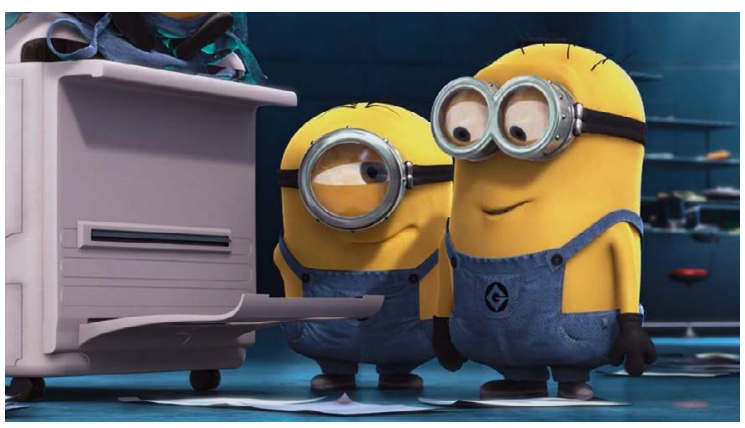

Fonte: Meu Malvado Favorito (2010).?

A dimensão visual compõe a imagem/ideia identitária dos minions como operários-servos, o que é reiterado pela dimensão verbal (a comunicação entre si e com o Gru), bem como pela dimensão vocal/musical do enunciado audiovisual, que, em sua unidade sincrética multimodal arquiteta a valoração enunciativa da animação.

Os minions, reunidos no laboratório em que trabalham para o Gru, recebem o comunicado acerca do novo serviço que realizarão: o roubo da Lua. Nessa cena (Figura 3), visualmente, a câmera seleciona o que podemos ou não olhar, bem como de que ponto de vista e, ao nos dar acesso à interação entre Gru e os minions, coloca Gru em uma posição de superioridade, em um palco, como uma celebridade, ao passo em que os minions, enquanto massa homogênea, encontram-se amontoados embaixo, aos pés de Gru. Assim, o jogo de câmeras, na dimensão visual, em movimento, marca a valoração e a hierarquia entre os sujeitos. Durante a cena, a câmera se 
alterna em mostrar a visão de líder do Gru (ao olhar para os minions) e a visão de submissão dos minions (ao olharem para o Gru), o que é confirmado pela entoação na dimensão vocal e pelo diálogo travado na dimensão verbal, quando assistimos ao filme de animação. Na Figura que segue, os olhares e as expressões dos minions (dimensão visual), de certa forma, revelam sua posição axiológica de veneração e obediência ao Gru, como se falassem (potencialidades verbal e vocal expressas pelo visual):

Figura 3 - Superioridade e inferioridade entre Gru e minions
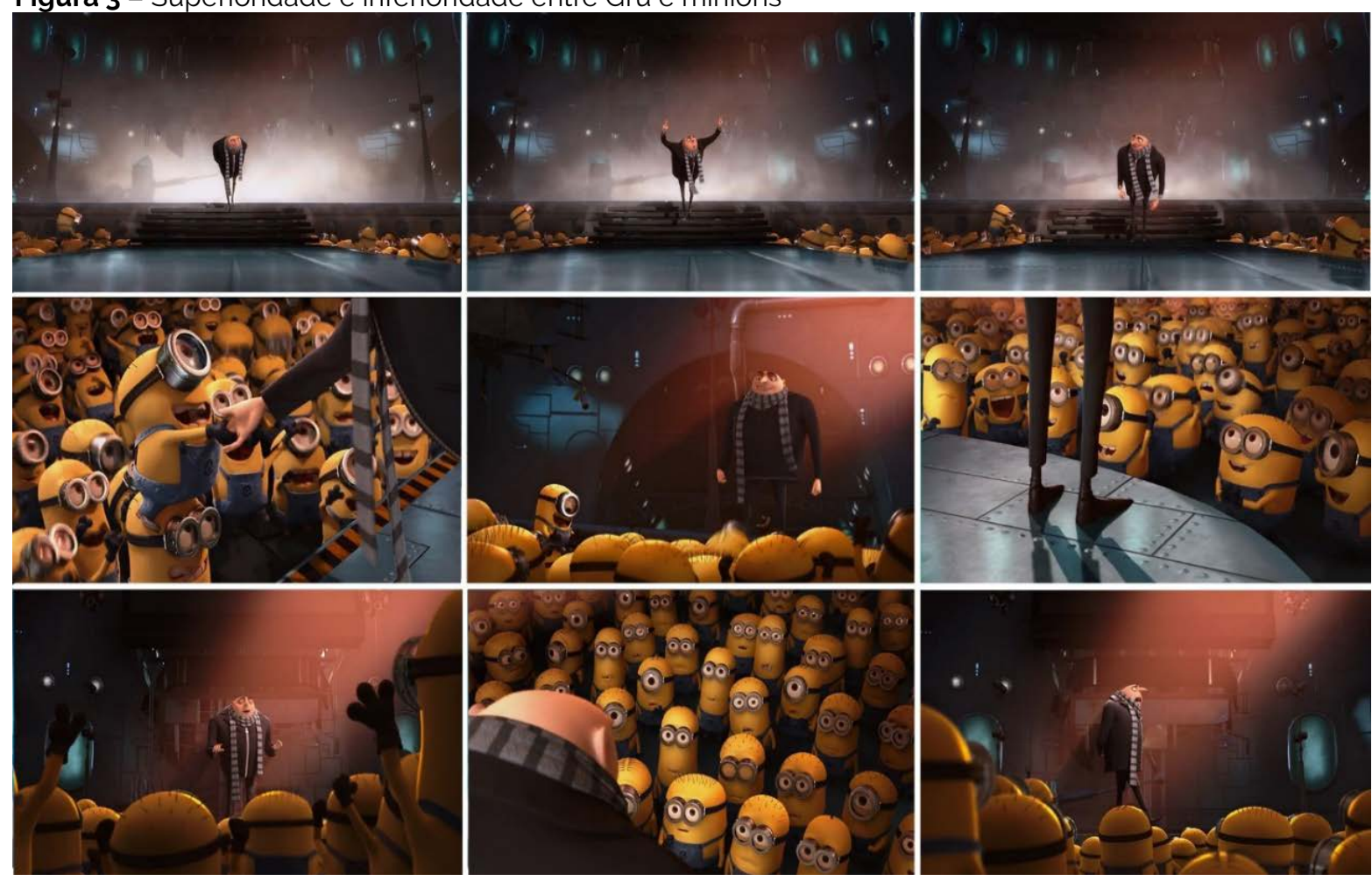

Fonte: Meu Malvado Favorito (2010). ${ }^{8}$

Em consonância com Bakhtin (2010), temos a ideia de sujeito construida a partir de um centro valorativo: eu-para-mim, eu-para-o-outro e outropara-mim. Os minions, concebidos como um grupo social destinado à servidão, enxergam em Gru a imagem do chefe a quem seguem fielmente e este se enxerga como um vilão repleto de subalternos que, mediante qualquer ordem, obedecem-no prontamente. Gru, o "eu", aproveita-se de seus "outros" para se constituir como o vilão mais temido do mundo, o mais famoso, entendido como o pior pela mídia e venerado por outros seus iguais, logo, no topo da sociedade vilânica. Todavia, sozinho, ele não alcança tal façanha, mas sim com a ajuda (servidão incondicional) de seus minions. $\mathrm{Na}$ relação de alteridade é que a identidade de Gru como o "Malvado Favorito" é constituida e ele passa a ser capaz de grandes feitos.

As realizações de Gru são colocadas na voz da primeira pessoa do plural, o "nós", como é possivel observar em uma das cenas de $\mathrm{Meu}$ Malvado Favorito (2010), em que ele diz, com um tom quase de cantoria, com a voz mais fina e mais branda (o que alia as dimensões verbal e vocal pela entoação): "Nós tivemos um ano de muita produtividade e vocês estão bem na fita comigo [...]. O que fizemos? Bem, nós roubamos a TV gigante do Times Square [...], roubamos a Estátua da Liberdade [...], e agora nós vamos roubar [...] a Lua!" (COFFIN; RENAUD, 2010, 00:09:22-00:11:17, grifo nosso). Sabemos que, de acordo com os

8 Fotogramas disponiveis em Meu Malvado Favorito (2010): 00:08:43, 00:08:44, 00:08:49, 00:08:50, 00:08:58, 00:08:59, 00:09:13 e o0:09:23. 
estudos bakhtinianos, as relações eu-outro se retroalimentam e invertem, a depender do ponto de vista; que "eu" e "outro" não coincidem, ainda que interajam e se constituam mutuamente um do outro. No caso citado, Gru utiliza "nós", "vocês" e "comigo" ("eu"), conforme seus interesses. A aproximação e o distanciamento marcados não apenas pelos pronomes nas dimensões verbal e vocal, mas também na dimensão visual, revelam a valoração e até o projeto de dizer do pronunciamento de Gru, em sua relação com os minions (convencê-los a assumirem a empreitada por ele idealizada, de roubar a lua). Em outras palavras, Gru ("eu") coloca os minions (seus "outros") no mesmo nível que ele ("nós") como estratégia retórica. Os minions (como "eu"), por sua vez, veemse/sentem-se contemplados nos resultados positivos obtidos pelo patrão ("outro"), e, assim, continuam a servi-lo, como antes, aparentemente, por escolha espontânea, colocada na animação como positiva (razão de sua existência).

Há, nesse sentido, uma ideia de outro-paramim (Gru para os minions) construída por meio do conteúdo verbivocal proferido por Gru. Contudo, o visual nos revela a diferença de posicionamento no mesmo ambiente, em niveis (superior e inferior) marcados (bem como os sujeitos que os ocupam). As câmeras mostram que Gru e minions não ocupam, de maneira alguma, a mesma posição nas aventuras que caracterizam o trabalho desses sujeitos. Gru é o patrão que planeja e ordena, enquanto os minions são os empregados que obedecem seu "Malvado Favorito". Gru é detentor dos meios de produção, de forma que ele está em posição privilegiada em relação aos minions, a mão de obra que o serve. Isso fica perceptivel pela disposição desses dois sujeitos na cena, no filme de animação e, transpondo telas e esferas, nas redes sociais e na política, como veremos adiante, na relação bolsominions e Bolsonaro.

Gru mantém uma relação com os minions que busca ser não só de patrão-servo, mas de aparente amizade e companheirismo, pois se coloca, com tópicos frasais repletos de "nós" e de verbos flexionados na primeira pessoa do plural, como em pé de igualdade com os minions, como se a parceria deles pudesse ser, de alguma forma, maior do que a relação patrão-servo. Entretanto, quando há a clara distinção de quem dá as ordens e fornece os meios de produção (Gru) e quem obedece e tem a força de trabalho (minions), essa igualdade se desconfigura e se confirma a diferença entre grupos sociais.

Ao pensarmos nos minions e na franquia dos filmes, podemos vislumbrar diversos outros enunciados-resposta que surgiram a partir deles, principalmente nas redes sociais, de modo que compreendemos, tal qual Bakhtin ao pensar sobre a noção de enunciado, que "[...] cada enunciado é pleno de variadas atitudes responsivas a outros enunciados de dada esfera da comunicação discursiva" (2011, p. 297). Ele sempre possui o caráter responsivo que o liga a outros enunciados (anteriores e posteriores), por isso, ao falarmos do termo "bolsominions", temos que traçar, mesmo que de forma breve, um perfil de sujeito minions em alteridade com Gru, para que possamos compreender não só a gênese do termo, mas as novas significações decorrentes dela, principalmente no Facebook, na relação eleitores e Bolsonaro, assim como Bolsonaro e Trump. Embora, como o título sugere, limitemo-nos a Bolsonaro neste artigo, por uma questão de espaço.

"Bolsominion", termo criado e em difusão no Facebook, é utilizado para se referir a um determinado perfil de eleitorado político. Sendo os bolsominions seguidores desse político, o Gru ("o malvado favorito") é a imagem do próprio político, uma vez que os minions se nutrem e vivem em função de um patrão a quem servir, assim como os bolsominions com o seu candidato e o Bolsonaro com o Trump, numa relação de subserviência colonial Brasil-Estados Unidos. Os eleitores-servos agem como degraus de uma escada para que um político atinja o alto escalão social, como representante máximo de uma nação (sempre relacionada a/em diálogo com outra).

O sujeito "bolsominion" está atrelado a uma imagem já construida dos sujeitos eleitores de Bolsonaro na rede social. Há uma relação entre o comportamento dos minions no filme e o dos bolsominions nas publicações do Facebook, de 
modo que um grupo de valores opostos os satiriza, por meio de memes e outros enunciados de humor. As publicações revelam o que, para os opositores aos "bolsominions", é motivo de critica e um discurso intolerante, ridiculo e preconceituoso.

Embora não seja nosso foco, trazemos, na Figura 4, por cotejo, uma publicação em que temos, de maneira resumida, o que é entendido por ser "bolsominion" pelo grupo que assim começou a utilizar o termo, como forma de crítica a esse eleitorado.

Na Figura, o uso do termo "bolsominions" aparece como uma categoria que agrega "tipos", de modo a caracterizar os diferentes perfis de sujeitos dentro de um grupo social ("bolsominions"). As imagens de minions em diferentes situações envolvem comportamentos presentes na vida, por sujeitos da vida e geram a ressignificação do termo "minions", da arte (filmes de animação), para "bolsominions", inicialmente utilizado nas redes sociais e, posteriormente, como caracterização de um grupo de sujeitos específicos, existentes na vida, mais especificamente na esfera política.

Figura 4 - Tipos de bolsominions

\section{TIPOS DE BOISO}

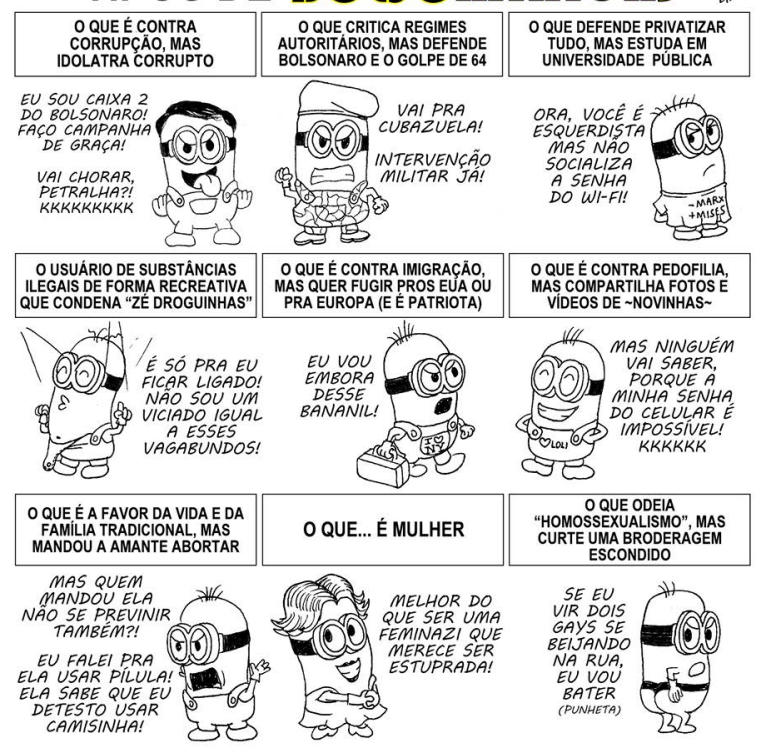

Fonte: Facebook - "Charges Contra o Coiso".9

Essa associação é feita com base nas aproximações de comportamento entre minions (personagens da animação) e bolsominions (personagens reflexo e refração de um grupo de eleitores), realizada por sujeitos-autores que veem no eleitorado político de Bolsonaro a imagem dos minions (que, como dito, são sujeitos alienados, voltados à servidão, à vilania e seguidores de um "malvado favorito") como, na ótica dos sujeitos refratantes, semelhantes aos apoiadores do político. O mais evidente é a defesa de uma cidadania do bem que nem os próprios defensores seguem, mas utilizam como álibi para embasarem seus discursos de ódio e de preconceitos, pois homofóbicos, racistas e machistas, contra os direitos humanos, a favor da "familia tradicional" heteronormativa, da "moral e dos bons costumes" conservadores, contra a corrupção (ainda que corruptos em seus atos cotidianos) e em defesa da Igreja (evangélica e parte da católica), em nome de um Deus vingativo e punitivo, cristãos que não seguem os preceitos defendidos por Cristo, a favor do armamento, da violência (simbólica e física), da pedofilia, do desmatamento e da subserviência capital.

Contudo, essa significação não é definitiva. A sua circulação permitiu respostas em embate, ou seja, a criação de novas significações para o mesmo signo linguístico, que, discursivamente, revelam um tom valorativo no signo ideológico, a depender de qual grupo o utiliza (favorável ou desfavoravelmente ao político em voga). Volóchinov, ao falar sobre tema e significação na lingua, pontua que "O sentido da totalidade do enunciado será chamado de seu tema" (2017, p. 227-228, grifo do autor), de modo que ele deve ser único para podermos falar sobre um determinado enunciado, individual e irrepetivel como o próprio enunciado o é, ao expressar a situação histórica concreta que o gerou. Assim, "[...] o tema do enunciado é definido [...] também pelos aspectos extraverbais da situação" (2017, p. 228) (vocais/sonoros e visuais - onde também cabe os gestos e as expressões, por exemplo). Sem eles, a sua compreensão não seria possivel.

No enunciado, junto ao tema, está a

9 Disponivel em: https://www.facebook.com/ChargesContraOCoiso/photos/a.187240738840982/193700214861701/?type=3\&theater. Acesso em: 21 out. 2018. 
significação, caracterizada como "[...] aqueles aspectos do enunciado que são repetiveis $e$ idênticos a si mesmos em todas as ocorrências" (VOLÓCHINOV, 2017, p. 228, grifo do autor). Tema não existe sem significação e vice-versa (p. 229). 0 termo "bolsominions" recebe novas significações, criadas em uma relação dialógica com o(s) uso(s) feito(s) anteriormente(s). Volóchinov afirma que "A pluralidade de significações é uma propriedade constitutiva da palavra" (2017, p. 230, grifo do autor). A sua significação não é a mesma sempre, pois, pelo movimento vivo da língua, desenvolvese e se amplia, segundo o autor.

Como o movimento é dialógico e não prevê um fim em si mesmo, o uso do signo ideológico não é cristalizado, mas adquire significações diversas. Isso é o que ocorre com o termo aqui analisado: a partir do uso feito pelo próprio grupo intitulado "bolsominion", que se apropriou do signo e o revalorou, o termo passou a identificálo, de forma positiva, em publicações também voltadas para o tema bolsominions, porém, com conteúdo temático heroico e nacionalista. A ressignificação é possivel porque, segundo Volóchinov, "[...] em torno de todo signo ideológico se formam como que círculos crescentes de respostas e ressonâncias" (2017, p. 101) e essa responsividade verbal, vocal e visual ocorre em embate valorativo, no interior do próprio signo ideológico, assim (dialogicamente) constituído.

Os posts seguintes revelam uma relação entre a imagem dos minions e as ideias defendidas pelos eleitores de Bolsonaro. Há uma aproximação do termo com a imagem veiculada pelos enunciados filmicos. O diálogo é estabelecido tanto de maneira intertextual quanto interdiscursiva. Nas páginas, a imagem dos minions, tal qual aparece ao longo dos filmes, reitera o que vemos nas telas: a imagem (dimensão visual), quando não no formato de recorte dos próprios enunciados filmicos, é trazida como montagem, de acordo com as publicações selecionadas abaixo. A referência aos filmes é utilizada pelo grupo que se representa como minion, numa relação de servidão voluntária positiva: os minions servem Gru, independente das circunstâncias, pois está na sua constituição esse traço de servidão fiel e cega. Assim também são os bolsominions. Afinal, como eles se posicionam diante do termo atribuido ao grupo reafirma e retoma os traços do signo ideológico "minions" dos filmes. Essa mesma referência ocorre também na representação Gru e Bolsonaro: o malvado favorito dos (bolso)minions, conforme a Figura 5.

Figura 5 - Os bolsominions e Bolsonaro

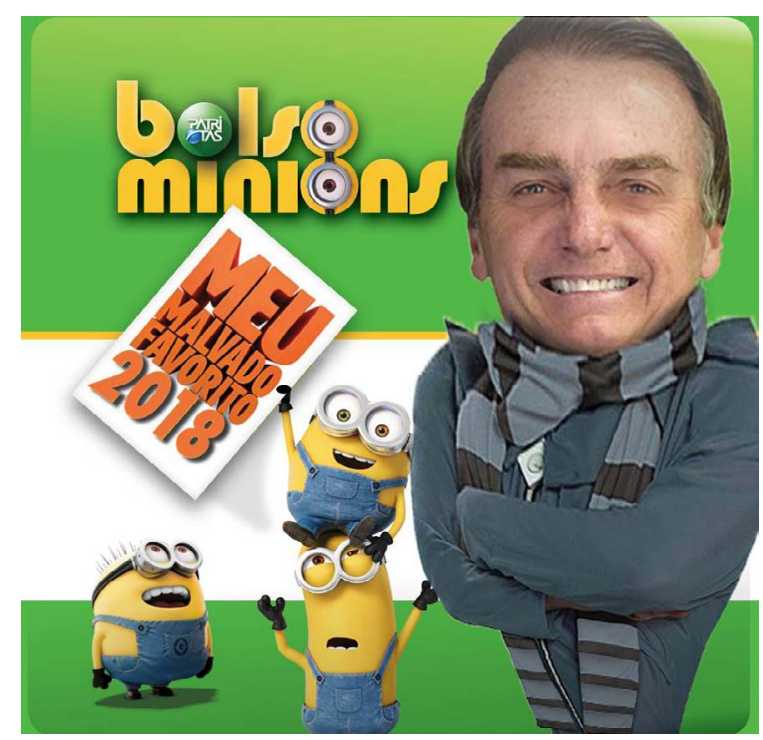

Fonte: Facebook - "Bolsominions Patriotas". ${ }^{10}$

Os bolsominions, que assim se afirmam, colocam-se em diálogo com os minions filmicos, pois além de utilizarem a imagem dos sujeitos amarelos como aparecem nos filmes, também utilizam suas ideias, ao se compararem a eles e ao compararem Bolsonaro ao Gru, o que fica evidente especialmente pelo visual nesse caso (pela vestimenta e o tamanho aumentado do Bolsonaro como "Meu Malvado Favorito"). Arte e vida, como Volóchinov pontua, estão correlacionadas, pois o estético e a vida mantêm relação, já que "A arte é também eminentemente social. [...] O estético lél tão somente uma variedade do social" (2013, p. 74, grifo do autor). Isso significa que o ato de linguagem artistica se encontra nas relações entre os sujeitos presentes na vida e é ressignificado ao ser levado da vida para a arte, elaborada com

10 Disponivel em: https://www.facebook.com/bolsominiosPatriotas/photos/a.331453604040148/409365169582324/?type=3\&theater. Acesso em: 16 fev. 2019. 
um determinado acabamento estético. A vida é matéria poética bruta que gera conteúdos ressignificados formal e estilisticamente. Esses enunciados estéticos voltam à vida à sua maneira, eticamente e são consumidos pelos sujeitos, das mais diferentes maneiras.

A presença de elementos em tons de verde e amarelo, cores que passaram a ser uma "marca registrada" desse grupo, como sinal de patriotismo por remeter às cores da bandeira do Brasil, é constante. Na Figura 5, os minions estão em segundo plano, segurando um cartaz escrito (verbal explicita o que está marcado também na dimensão visual) "Meu Malvado Favorito 2018", em referência à campanha eleitoral de Bolsonaro para presidente, ao passo que o candidato, em primeiro plano e em destaque, assume a imagem do malvado favorito aclamada pelos (bolso)minions, seus servos, que se encontram atrás dele, como seus seguidores. A montagem feita entre Gru (corpo/vestimentas) e Bolsonaro (cabelo/rosto) revela quem é o malvado favorito que os (bolso)minions, ao fundo, apoiam: Bolsonaro. A presença do termo "bolsominions" é feita com a mesma tipografia (verbivisual) do filme Minions (2015), o que aproxima, mais uma vez, a arte da vida, de maneira ressignificada. Os minions estão vestidos com o seu típico macacão jeans de operário. Eleitores idênticos aos sujeitos amarelos da animação, em aparência e essência de escravidão voluntária.

O discurso intolerante dos bolsominions pode ser depreendido nas três publicações que seguem (Figuras 6, 7 e 8), com a temática do feminismo (movimento que objetiva, dentre outras questões, a libertação de padrões patriarcais, principalmente ao que tange à mulher, em defesa da igualdade de direitos e tratamento entre gêneros). Ao criticarem as feministas (por meio da ridicularização e da comparação), os bolsominions se posicionam de maneira ativa e revelam as valorações acerca do que compreendem por feminismo, bem como acerca de outras questões relacionadas a esse movimento.
Figura 6 - Bolsominions e feministas

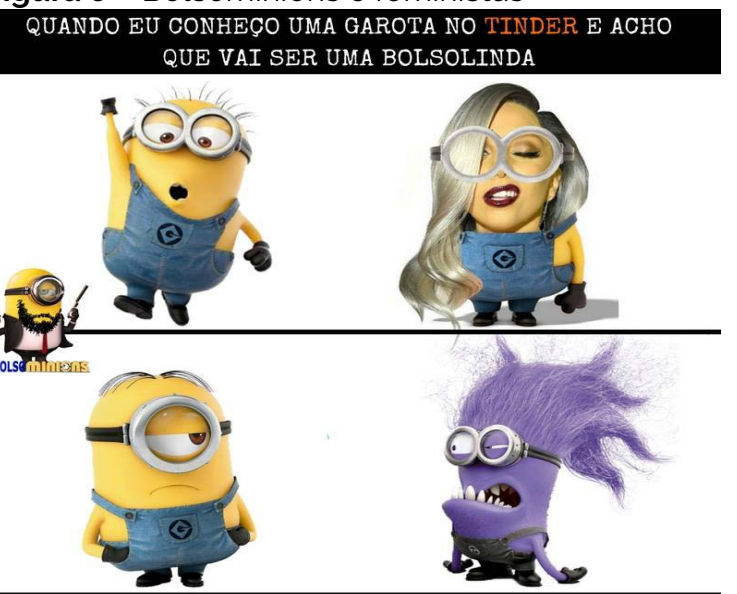

AI CHEGO LÁ E É UMA FEMINISTA

Fonte: Facebook - "Bolsominions". ${ }^{11}$

O humor, presente no enunciado da Figura 6 (de acordo com e para esse grupo), encontra-se na comparação entre uma "bolsolinda" e uma "feminista". Ser "bolsolinda" é o padrão visual esperado de mulher (não apenas para esse grupo): loira platinada e com batom vermelho, elementos simbolicamente tidos como femininos e sexy socialmente. O bolsominion ao lado da "bolsolinda" comemora a imagem de mulher criada, com expectativa positiva, calcada em um estereótipo que agradaria aos homens e coloca a mulher como objeto de desejo sexual, a serviço desses homens. Nesse sentido, uma "bolsolinda", hierarquicamente, é (ou deve ser, pela expectativa criada no post) ainda mais servil que o "bolsominion", pois ela deve servir a ele (bolsominion), tanto ao compactuar com sua submissão política, econômica e social, quanto por se colocar à sua disposição, como sujeito-objeto de desejo do homem, pelo padrão esperado por ele.

O termo verbal utilizado para se referir a essa mulher sofre alteração que marca, linguisticamente, a valoração a ela incutida: ser eleitora e seguidora do mesmo político escolhido pelos bolsominions e ser objeto sexual à disposição do bel prazer dos sujeitos amarelos (designados, sempre, no masculino). Isso fica marcado pela composição etimológica do signo que nomeia (como "bolso")

11 Disponivel em: https://www.facebook.com/bolsominions1.0/photos/a.110389262990086/111239602905052/?type=3\&theater Acesso em: 16 fev. 2019 . 
essa mulher e, ao mesmo tempo, a qualifica (como "linda"), num substantivo-adjetivo que consiste, pela aglutinação, em juntar o termo "bolso", de Bolsonaro, que cumpre a função de radical do lexema (também presente em "bolsominions") com o adjetivo "linda", qualitativo que passa a designar (adjetivo substantivado que funciona como morfema de gênero na composição desse signo) identitariamente quem, como e o que é a mulher eleitora de Bolsonaro, almejada/desejada pelos bolsominions. A valoração da mulher está impressa no léxico e se confirma no visual e no entoativo vocal (a oralidade expressa pelo "Ai", que marca a quebra de expectativa e engata o enunciado numa musicalidade discursiva potencial).

A Figura 6 está visivelmente dividida em duas partes. Na primeira, colocada, não por acaso, na parte superior, relacionada à expectativa pela narrativa que revela a idealização ("achar" que, logo, esperar) sobre uma mulher, marcada como "bolso" e como "linda"; em contraposição à realidade para e de um bolsominion homem (ser diferente do imaginado, uma feminista, colocada no segundo plano da Figura 6 , também não fortuitamente, na parte inferior da imagem). A narrativa, escrita em primeira pessoa do singular ("eu"), demonstra a frustração do homem ao se deparar/encontrar com uma mulher que não coincide com o padrão por ele desejado e socialmente esperado e aceito.

$\mathrm{Na}$ segunda parte da publicação, um bolsominion desaprova, com olhar de desdém (no visual), o que seria um minion do mal no desenho e que, no post, representa o que esse grupo entende por e chama de feminista (no verbal). A minion feminista, além de ser colocada como uma mulherminion fora de controle (num ato típico machista que denomina qualquer mulher que responda de maneira não esperada e aceita socialmente como "louca"), em comparação com a "bolsolinda", é caracterizada pelo que pode ser considerado por esse grupo bolsominion como "feia", uma vez que, na dimensão visual, é caracterizada como roxa, descabelada, com dentes tortos, boca aberta e olhos irregulares. A valoração fixa voltada à mulher se centra, para esse grupo (que revela uma voz social machista padrão), na beleza (padrão) e na objetificação sexual.

A marca da página aparece em todas as suas publicações. Nesse post, a logo, que é a identidade visual da página, funciona como a sua assinatura autoral e expressa o posicionamento do criador, que sempre critica opositores a Bolsonaro e assume o signo "bolsominion" com tom positivo. Essa logo, constituida por um bolsominion de terno, com barba e arma nas duas mãos, aparece no meio da Figura 6, no canto esquerdo e revela hierarquia (a autoridade do autor-criador da página fica marcada pela roupa do minion), poder (explicitado pelas armas e pela expressão do minion, colocado como "lacrador" pela ridicularização machista e discriminatória da publicação) e nacionalismo (expresso pelas cores, azul e amarelo, que remetem à bandeira do Brasil, no título da página).

Ao associarem a imagem de feministas com os minions do mal do filme Meu Malvado Favorito 2, os autores-criadores valoram o que entendem por feministas: mulheres que não atendem ao padrão esperado de mulher (loira, de cabelos lisos, compridos e maquiada). Ao contrário. A mulher que não é "bolsolinda", é feminista e ser feminista significa, para esse grupo, ser do mal e monstruosa.

Outro exemplo (Figura 7) sobre o posicionamento ao que concerne ao movimento feminista expressa o discurso intolerante desse grupo. Para os bolsominions, conforme a Figura 7, ser feminista, além da representação de um minion do mal (que, nesse caso, está com a coloração vermelha - marca registrada do PT - Partido dos Trabalhadores, do comunismo e das revoluções, em sua visão), com os olhos arregalados, o cabelo bagunçado e a postura do corpo torta, também está ligada às palavras "patriarcadu" (patriarcado) e "imponderada" (empoderada), escritas de tal forma, propositalmente, para relacionar esse registro linguistico, de maneira preconceituosa, à falta de conhecimento que o grupo associa aos eleitores políticos contrários aos bolsominions. Em sincrese, as dimensões verbivisual marca a voz entoacional (vocal) discursiva potencial do autor-criador e do grupo social que se autodesigna "bolsominion". 
A mulher feminista, nessa imagem (7), é chamada de "vermínia", lexema (dimensão verbal) que pode ser relacionado à sua cor ("vermelha"), menina vermelha; mas também, por associação fonética, pode ser relacionado a "verme". Nos dois casos, o termo é depreciativo, escrito com um registro de língua com marcas de oralidade (dimensão vocal) e com o que, numa abordagem tradicional, normativa, é considerado "erro" e denota um preconceito linguistico que explicita discriminação de classe e gênero. Além disso, a mulher do post (na dimensão visual) persegue os bolsominions que, patriotas, vestidos com seu típico macacão de operário, mas, agora, verde e com a bandeira do Brasil estampada no peito, correm/fogem dela.

Figura 7 - Bolsominions e feministas

Si a verminia dizeu: "patriarcadu", "impoderada". Sai correndu qui é fria.
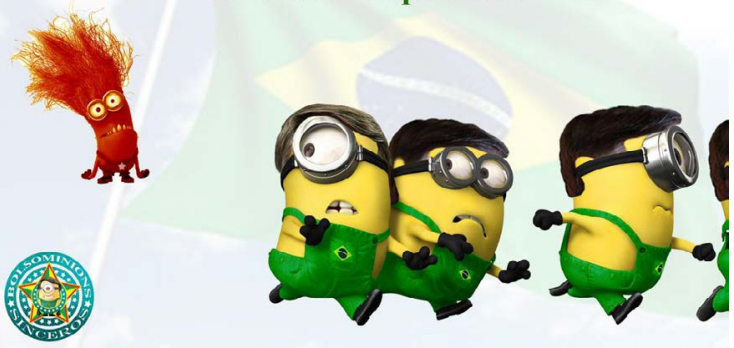

Fonte: Facebook - "Bolsominions Sinceros". ${ }^{12}$

O patriotismo está presente não apenas no macacão de operários verde com a bandeira estampada no peito dos bolsominions, mas também na bandeira do País, em segundo plano, como marca d'água que ambienta a cena visualmente.

Os bolsominions são caracterizados, na Figura 7, com o cabelo penteado para o lado, semelhante ao que o politico defendido utiliza. Essa alteração (marcada pelo cabelo, no visual) engata os bolsominions na cadeia discursiva da esfera política, situada no periodo das eleições presidenciais de 2018 no Brasil.

Na imagem 8, o humor está, mais uma vez, associado à imagem de mulheres feministas, retratadas de maneira pejorativa, entendida, por esse grupo, como ridícula, risivel, monstruosa, perseguidora, objetificada e motivo de piada.

Figura 8 - Bolsominions e feministas

\section{SABEM AS SEMELHANÇAS ENTRE AS FEMINISTAS E 0 MIOJO? FICAM PRONTAS EM 3 MINUTOS E SÃO COMIDA DE UNIVERSITÁRIOS}

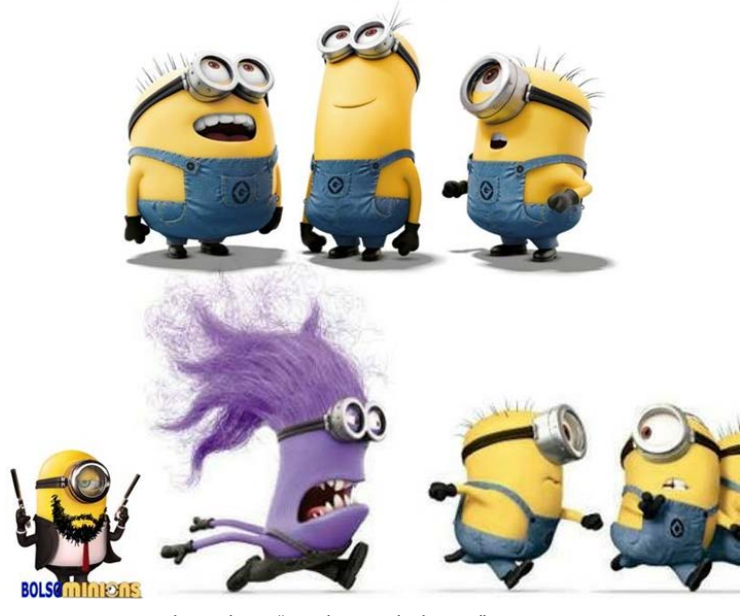

Fonte: Facebook - "Bolsominions".13

No caso dessa Figura (8), a comparação verbal é feita entre "feministas" e "miojo". O ponto de semelhança entre os dois é que "ficam prontas em 3 minutos e são comida de universitários". Mais uma vez, a imagem (visual) de mulher é objetificada, depreciada, ofendida e a de mulheres feministas é expressa por um minion do mal (braços longos e desajeitados, cabelo bagunçado e dentes tortos à mostra), enquanto a imagem dos minions é, mais uma vez, associada aos bolsominions - por identificação - como positiva.

Na parte superior (visual) dessa Figura, há apenas os bolsominions, com a cabeça erguida, como forma de atenção e direcionamento ao questionamento verbal da publicação: "Sabem as semelhanças entre as feministas e o miojo?". Abaixo, os bolsominions correm, como uma forma de fugir da minion feminista monstruosa.

A imagem da mulher feminista que corre atrás dos bolsominions, representada como um monstro, má, descontrolada, sem cultura

\footnotetext{
Disponivel em: https://www.facebook.com/bolsominionssinceros/photos/a.118917445623039/118917675623016/?type=3\&theater Acesso em: 26 maio 2019 .

13 Disponivel em: https://www.facebook.com/bolsominions1.0/photos/a.110389262990086/110755476286798/?type=3\&theater. Acesso em: 16 fev. 2019
} 
e objetificada é recorrente. O desrespeito com a mulher, mesmo quando descrita como "bolsolinda", é uma marca do machismo constitutivo desse grupo e do candidato a que servem e veneram.

Por meio dessas três publicações, que circulam nas redes sociais, compreendemos o que representa, para os bolsominions, temas sociais (como o feminismo, que consiste em pensar a estrutura patriarcal de nossa sociedade, além do empoderamento feminino), entendidos como questões risiveis, de forma que uma de suas pautas torna-se a chacota sobre esse assunto, como ocorre nas publicações, que mostram a intolerância com um movimento político e social em busca de igualdade.

Ao se apropriar do termo "bolsominions" e passar a se autodenominar assim, esse grupo mudou não só a significação do termo, colocada como positiva, como também manteve, em certa medida, a significação original atribuída ao grupo, por meio de suas pautas, versadas sobre um discurso de ódio e de intolerância. O ato de apropriação consiste em esvaziar o sentido antes atribuido. Segundo Batista (2018, p. 213), o termo apropriação carrega uma "ideia de uma ação de deslocamento de uma coisa à outra, movimento em que o objeto deslocado permanece junto ao outro".

Os bolsominions mudaram o sentido original (como visto na Figura 4), inverteram valorações (e, de certa forma, confirmam outras) para, então, afirmarem-se e se autodenominarem como tal, ao estabelecerem uma relação de identidade e pertencimento, de modo que o espaço é uma expressão de si (BATISTA, 2018, p. 220).

Pensamos em como a eleição, e a consequente vitória de um político que materializa (enquanto discurso de autoridade) determinadas valorações, faz com que esse tipo de discurso intolerante emerja, cada vez mais e de maneira mais visivel, em pessoas que o sustentam e corroboram com esse tipo de comportamento, ideais e pensamentos, fazendo, do espaço (o território nacional), uma expressão (extensão?) de si e de suas valorações - seu posicionamento ético no existir. A temática do feminismo (apresentada em publicações diferentes) foi uma forma de observar como esses sujeitos atuam em rede, defendendo seus valores morais "cristãos", familiares e cidadãos.

\section{Considerações finais: o ser "bolsominion"}

Como visto, o termo "bolsominions" foi (e é) produzido e circula nas redes sociais (especificamente, no Facebook), assim como ultrapassou esse espaço e passou a designar um posicionamento político, com valoração diferente, a depender do grupo que o utiliza - pois cada uso carrega posicionamentos diferentes, que se entrecruzam, mas revelam vozes dissonantes. Voltamos o nosso olhar, em específico, para as formas de expressão dos sujeitos (assumidos) bolsominions em rede, pois revelam como esse grupo social concebe o mundo e como (re) significa suas práticas sociais.

Volóchinov diz que "[...] uma mesma palavra nos lábios de pessoas de classes distintas reflete também pontos de vista distintos, mostra relações diferentes com a mesma realidade, com o mesmo fragmento da realidade que constitui o tema daquela palavra" (2013, p. 197, grifo do autor). Um termo deve ser visto de acordo com as condições socio-históricas de seu uso, uma vez que elas revelam não só as valorações que circulam num momento, mas também permitem compreender os embates em torno de um mesmo signo ideológico, usado de diferentes maneiras para propósitos distintos.

Os sujeitos, enquanto autores, escolhem as suas palavras na vida e valoram o signo ideológico de acordo com suas vivências, respondendo, ativamente, às visões de mundo às quais se filiam e se constituem como sujeitos - tanto quem critica quanto quem se identifica como bolsominion. As referências podem ou não serem explícitas, mas elas existem como potencialidade enunciativas de linguagem, como entende Paula (2017a, 2017b, 2017c, 2019a, 2019b), a partir do Círculo bakhtiniano, a verbivocovisualidade e são uma forma de compreender o sujeito no mundo, em seu lugar único na existência, ao interagir com o mundo que o circunda. Por isso, 
não podemos pensar, seja qual for o uso feito do termo, em álibi, pois agir no mundo, por meio de enunciados, além de ser uma responsividade, é, também, uma responsabilidade.

Ao compreendermos como a ideologia compõe o signo, por meio do tema e da significação, em enunciados que ressignificam as questões de alteridade - e revelam, dessa forma, as identidades (dos bolsominions, em um tempoespaço específico) -, percebemos como esse termo passou de crítica satírica de um grupo social para identificação de um outro. Observar esse movimento significa refletir sobre a língua e a linguagem em seu uso vivo, pois isso revela que cada sujeito, em suas relações particulares, compreende o mundo à sua maneira e essa forma de compreensão está em (ou pode vir a ser) embate de valores com a compreensão do outro. Condição necessária para que se continue tendo usos vivos da língua/linguagem e que a língua/linguagem, tanto em sua potencialidade quanto em sua materialidade verbivocovisual, não seja compreendida de um ponto de vista clínico, estático, meramente técnico e estrutural, como se existisse neutralidade que, sabemos, é inexistente - o que pôde ser exemplificado pela análise aqui realizada - mas sim como arena viva.

A partir de uma franquia de enunciados filmicos de animação, vimos como a arte e a vida estão relacionadas não só no momento de produção, mas também de recepção e de circulação, o que revela como a sociedade lida (e tem lidado) com enunciados que, de uma forma ou de outra, semiotizam-na axiologicamente.

Mostrar como os bolsominions (da vida, seja nas redes sociais seja na esfera política) surgiram a partir dos minions (da arte) é uma forma de compreender o funcionamento discursivo dos enunciados que circulam em nosso convivio social e como o signo ideológico "bolsominion" passa a ser um termo incorporado em nosso vocabulário desde as eleições de 2018 para identificar determinado grupo, com valorações distintas, a depender do ponto de vista dos sujeitos.

Ao percebermos que há uma ideia de minions presente nos filmes, a associação com os bolsominions e com o consequente desdobramento do termo nos permite pensar sobre a expressão dos sujeitos em um tempoespaço (cronotopo) especifico. Buscamos mostrar, neste artigo, como esse momento específico da história (o cenário político brasileiro de 2018 , entendido como pequeno tempo) suscitou vozes sociais em formatos de enunciados especificos, que nos permitem compreender como esses grupos têm se organizado, manifestado e atuado no mundo, de certa forma, marcando um grande tempo histórico, em construção e a ser estudado, compreendido e transformado.

\section{Referências}

BAKHTIN, Mikhail. Questões de literatura e de estética: a teoria do romance. São Paulo: Hucitec, 2014.

BAKHTIN, Mikhail. Estética da criação verbal. São Paulo: WMF Martins Fontes, 2011.

BAKHTIN, Mikhail. Para uma filosofia do ato responsável. São Carlos: Pedro \& João, 2010.

BATISTA, Carmem Lucia. Os conceitos de apropriação: contribuições à Ciência da Informação. Em Questão, Porto Alegre, v. 24, n. 2, p. 210-234, maio/ago. 2018. https://doi.org/10.19132/18085245242.210-234

COFFIN, Pierre; BALDA, Kyle. Meu Malvado Favorito 3. Universal: EUA, 2017, $89 \mathrm{~min}$.

COFFIN, Pierre; BALDA, Kyle. Minions. Universal: EUA, 2015, $91 \mathrm{~min}$.

COFFIN, Pierre; RENAUD, Chris. Meu Malvado Favorito 2. Universal: EUA, 2013, $98 \mathrm{~min}$.

COFFIN, Pierre: RENAUD, Chris. Meu Malvado Favorito. Universal: EUA, 2010, 95 min.

FARACO, Carlos Albero. Linguagem \& diálogo: as ideias linguísticas do círculo de Bakhtin. São Paulo: Parábola, 2009.

JENKINS, Henry. Cultura da convergência. São Paulo: Aleph, 2009.

LÉVY, Pierre. A inteligência coletiva: por uma antropologia do ciberespaço. São Paulo: Loyola, 2007.

OLIVEIRA, Natasha Ribeiro de. A febre amarela "minions": uma análise bakhtiniana. Dissertação (mestrado) - Araraquara: Programa de Linguística e Lingua Portuguesa da Faculdade de Ciências e Letras da UNESP Araraquara, 2020 (Mimeo).

PAULA, Luciane de. Verbivocovisualidade: uma abordagem bakhtiniana tridimensional da linguagem. Projeto de Pesquisa em andamento. UNESP, 2017a (Mimeo). 
PAULA, Luciane de. O enunciado verbivocovisual de animação - a valoração do "amor verdadeiro" Disney - uma análise de Frozen. Discursividades Contemporâneas - política, corpo e diálogo. Campinas: Mercado de Letras, 2017b, p. 287-314.

PAULA, Luciane de; SERNI, Nicole Mioni. A vida na arte: a verbivocovisualidade do gênero filme musical. In: Raido, Dourados, v. 11, n. 25, p. 178-201, jul. 2017c. https://doi.org/10.30612/raido.v11i25.6507

PAULA, Luciane de; SILVA, Tatiele Novais. Nerve à flor da linguagem: arte e vida em jogo dialógico. Diálogo das Letras, Pau dos Ferros, v. 8, n. 2, p. 38-57, maio/ago. 2019a.

PAULA, Luciane de; OLIVEIRA, Fábio Augusto Alves de. O signo "resistência" nas eleições presidenciais de 2018 no Brasil Revista ENTRELETRAS, Araguaina, v. 10, n. 2, p. 350-371, jul./dez 2019b.

PAULA, Luciane de; FIGUEIREDO, Marina Haber de; PAULA, Sandra Leila de. O Marxismo do/no Círculo. Slovo - o Círculo de Bakhtin no contexto dos estudos discursivos. Curitiba: Appris, 2011, p. 79-98.

VOLÓCHINOV, Valentin. Marxismo e filosofia da linguagem: problemas fundamentais do método sociológico na ciência da linguagem. São Paulo: Editora 34, 2017 [1929].

VOLOCHÍNOV, Valentin. A construção da enunciação e outros ensaios. São Carlos: Pedro \& João, 2013.

\section{Luciane de Paula}

Doutora em Linguística e Lingua Portuguesa pela Universidade Estadual Paulista (UNESP, Araraquara, SP, Brasil), Campus de Araraquara. Professora da Universidade Estadual Paulista (UNESP, Araraquara, SP, Brasil), Campus de Assis, do Programa de Pós-graduação em Linguistica e Lingua Portuguesa da Campus de Araraquara e do ProfLetras. Coordenadora do GED - Grupo de Estudos Discursivos.

\section{Natasha Ribeiro de Oliveira}

Doutoranda em Linguística e Lingua Portuguesa pela Universidade Estadual Paulista (UNESP, Araraquara, SP, Brasil), Campus de Araraquara. Membro do GED Grupo de Estudos Discursivos. Apoio FAPESP/CAPES - Processo n. ${ }^{\circ}$ 2017/26629-3.

\section{Endereço para correspondência}

Luciane de Paula/ Natasha Ribeiro de Oliveira

Universidade Estadual Paulista

Rodovia Araraquara-Jaú, Km 1

Machados, 14800-901

Araraquara, SP, Brasil 